\title{
When Defense Becomes Offense: The Role of Threat Narratives in the Turkish Civil War of the 1970s
}

\section{Meral Ugur Cinar}

To cite this article: Meral Ugur Cinar (2014) When Defense Becomes Offense: The Role of Threat Narratives in the Turkish Civil War of the 1970s, Turkish Studies, 15:1, 1-11, DOI: 10.1080/14683849.2014.891351

To link to this article: https://doi.org/10.1080/14683849.2014.891351

曲 Published online: 13 Mar 2014.

Submit your article to this journal $₫$

Џll Article views: 402

View Crossmark data $\complement$

Citing articles: 1 View citing articles ๘ 


\title{
When Defense Becomes Offense: The Role of Threat Narratives in the Turkish Civil War of the 1970s
}

\author{
MERAL UGUR CINAR \\ Department of Political Science and Public Administration, Bilkent University, Ankara, Turkey
}

ABSTRACT This article examines the role of threat narratives in the process of group mobilization for political violence, focusing on the Turkish civil war of the 1970s. It argues that threat narratives promote political violence by identifying a certain politically mobilized group as "the enemy," and they incite fear in people against this group. Threat narratives further broaden the cycle of violence by deliberately conflating and expanding the category of the enemy and leaving no space for neutrality or moderation.

\section{Introduction}

Why do people resort to political violence, to the point of even killing others and/or themselves? Scholars have sought to explain this widespread phenomenon for decades. While commonly identified factors, such as the hierarchical structure of organizations, the urge for obedience to commands, and the strategic use of violence in order to achieve certain goals, ${ }^{1}$ are certainly important, they are not sufficient for understanding what actually persuades or motivates people to join violent movements. As Tishkov argues: "In order to fight effectively one should not only be trained on how to master Kalashnikovs and grenade launchers but also be able to explain why it is necessary to fight, who is the enemy, and why it is the warrior's honor to die for a nation." 2

Across the variety of particular circumstances that can trigger a violent act, the deployment of threat narratives ${ }^{3}$ is essential in explaining large-scale political violence. As Bar-Tal argues, fear is "an evolutionary safeguard that ensures survival in view of potential threats and dangers that human beings encounter. Fear is a fundamental mechanism, easily evoked, that governs human consciousness." Fear motivates protection from events that are perceived to be a threat, which is realized in the form of defense from or aggression against the source of the perceived

Corresponding Address: Meral Ugur Cinar, Department of Political Science and Public Administration, Bilkent University, Ankara, Turkey. Email: meral.ugur@bilkent.edu.tr 
threat. ${ }^{4}$ Fear and threat are transmitted through narratives. In order to promote participation in political violence, a conflict needs to be put in a narrative form that makes sense to the anticipated participants. Politically significant ideas are conveyed through narratives. Scholars such as Ricoeur, MacIntyre, Taylor, and Bruner have shown that human beings understand, evaluate and communicate social phenomena in narrative form. ${ }^{5}$ More specifically, Somers argues that social identities are constituted through narratives, ${ }^{6}$ and Smith shows the constitutive nature of stories for different forms of peoplehood. ${ }^{7}$ From these perspectives, it is necessary to focus on narratives that create a web of meaning around separate images and events and facilitate the transmission of political ideas. In this regard, Rotherbarth and Korostelina see threat narratives as major sources of identity-based conflict. They argue that these narratives are often used to exploit intense and powerful imaginaries. According to their analysis, threat-logic includes a demand for security that is impossible to attain. The only way to attain peace and escape from threat, those caught in this logic believe, is to continue the means of the conflict. This logic is responsible for cycles of violence. ${ }^{8}$

The theoretical framework outlined above can illuminate important and insufficiently explored aspects of the Turkish civil war ${ }^{9}$ of the 1970s. It is of course important to take into consideration the global context and the international strategic configuration of the Cold War era when analyzing the Turkish civil war. One should not forget, however, that people had to be persuaded to carry out the killings, a phenomenon that was facilitated by threat narratives. An emblematic example of the militants' hesitation in taking the lives of others can be seen in the words of Mustafa Yalçıner, a student of the Middle East Technical University and a member of the illegal leftist organizations People's Liberation Army of Turkey (THKO, Türkiye Halk Kurtuluş Ordusu) and Revolutionary Youth (Dev-Genç). When he went to rural areas of Turkey to begin guerilla war operations alongside his friends, he wrote the central question in his diary on March 27, 1971: "All right, everything is ready now, but the question is: how will we be able to kill men? That is the whole issue." 10 This question captures many of the dynamics of the Turkish civil war. Participants in the armed struggle were, on average, in their early 20s. Many of them were either high school or university students. A strong motivation was needed to make them kill individuals with whom they had no personal grievance. As the armed conflict intensified, the initial hesitation expressed in Yalçıner's diary entries faded. Killings increased steadily by both the left and the right. As this article will show, threat narratives played a central role in the acceleration of violence.

It is with this theoretical background that this article examines the role of threat narratives in the Turkish civil war, in order to show how threat narratives were deployed to justify violence, both by the propagandists and the participants. It argues that the escalation of political violence follows the following steps: first, groups identify a certain politically mobilized group as their enemy and build a threat narrative around this group. Second, the mobilized opposition group is associated with a broader group of people, who are not actually part of the violent conflict. 
Third, the content of the enemy is further broadened with the help of threat narratives so as to also include those who want to remain neutral as well as the moderates.

The deadly conflict in Turkey involved both radical leftists and rightists. This article will focus on Turkish ultranationalists (úlkucú) who took part in political violence during the 1970s. The link between mass movement and political party was clearer in the case of the radical right. The movement was more united compared to the left. The leaders of far right youth organizations had organic ties to the Nationalist Action Party (NAP, Milliyetçi Hareket Partisi). ${ }^{11}$ This close association enables us to analyze the speeches and writings of the party elite as part of the study of the violent ultranationalist groups in Turkey. This study will show us that the involvement of a large number of people in violent movements cannot be explained with compulsion alone. Self-persuasion, based on the idea of the "need for self-defense" (the self being the individual, his/her family, the nation, the regime, etc.), plays a central role in the mobilization of the masses.

The article is divided into three parts. It first provides a brief historical overview of the political violence of the 1970s. It then analyzes the mobilization of threat narratives. It shows how propaganda at the elite level was based on "threat" and "defense." The category of the enemy was thus blurred, collapsing too many categories into one and leaving no space for neutrality or moderateness. Finally, it turns to the reception of threat narratives by the participants of political violence. Threat narratives that were deployed at the elite level as propaganda rhetoric provided motivation and justification as to why violent groups killed others.

\section{Turkish Low-Intensity Civil War}

Ultranationalist groups were formed as a reaction to the rise of the left in Turkey starting in the late 1960s. The first Hearth of Ideal (Ülkü Ocă̆l) was formed on March 18, 1966. This movement's reflection in the political arena was the NAP. Its leader, Alparslan Tưrkeş, declared that the NAP had "educated" 250,000 youth. ${ }^{12}$ Organizations such as the Association of Hearths of Ideal (Ülkü Ocaklarl Derne ği, AHI) and Idealist Youth Association (IYA, Ülkücü Gençlik Derneği) were formed. ${ }^{13}$ In 1968, Bozkurtlar ${ }^{14}$ was increasingly present in the streets of larger cities, especially in Ankara and Istanbul. Their numbers were estimated to be between several hundred and a few thousand. ${ }^{15}$ They were trained in camps known in the public as "commando camps." ${ }^{16}$ Within the NAP, the Bozkurtlar were known as "Anti-Communist Street Forces." 17 Their camps, which were first established in 1968, aimed at creating armed forces that could fight against the rural guerilla forces of the radical left. In August 1968 Túrkeş proudly stated: "We certainly do have nationalist children who can talk the same language as the communist [read armed struggle]."18

The years between 1968 and early 1970s witnessed armed fights at universities, in which many students lost their lives. These right-left conflicts became part of everyday life; people were killed on a daily basis. Assassinations and kidnaping were also common. Turkey began to live the conditions of a civil war after $1976 .{ }^{19}$ In the months preceding the military's intervention in September 1980, the death toll had 
risen to more than 20 people per day. ${ }^{20}$ The military regime harshly suppressed both parties, particularly the left, bringing the street fightings to an end.

\section{“Communists, Go to Moscow!': Anti-Leftist Propaganda}

The radical right used all forms of media to communicate the "existential threat" posed by the communists. This propaganda was organized at the elite level, as the writings of Dündar Taşer in the newspaper Devlet show. Taşer, the mastermind and co-founder of the commando camps, also gave lectures to the youth members of the party branches. Devlet was founded in April 1969 and operated like the media branch of NAP. In his piece dated 30 March 1970, ${ }^{21}$ Taşer depicts leftists as awkward, ignorant, and opportunistic liars. ${ }^{22}$ On April 20, 1970, he associates communists with illness, bad deeds and betrayal. ${ }^{23}$ People who believe in different shades of left-wing ideology are automatically equated with armed communists. Differences, including diverging attitudes toward armed conflict, are ignored.

The idea that the communists were the biggest enemy of the nation was also preached by the NAP leader Túrkeş on every occasion. Túrkeş defined communism as an ideology that tried to turn the Turkish nation into slaves. ${ }^{24} \mathrm{He}$ described communism as an "international ideology with a secret invasion plan." ${ }^{25}$ The idea that communists were both internal enemies and accomplices of external enemies who wanted to invade Turkey, was a common trope, and was embedded in the context of the Cold War and the Soviet Union's policies. For instance, an influential journalist closely associated with the NAP, Cemal Anadol, framed the nationalists' struggle with the communists as an effort to prevent Turkey from becoming Afghanistan. ${ }^{26}$ In parallel, Tưrkeş in an interview with the Soviet daily newspaper, Konsomoskaya Prada, said that, as NAP, they had never forgotten how Afghanistan was invaded by the Soviet military and that they had thought that the same thing would happen in their country. ${ }^{27}$ By invoking the Soviet invasion of Afghanistan in their discussions of the left in Turkey, NAP's leadership and ideologues were referring to a vividly threatening image in recent word history. The fact that the example was from another predominantly Muslim state further strengthened the analogy and amplified the threat.

Telling young people about these communist "collaborations," the party leadership invited the youth to fulfill their "duties." NAP anti-communist propaganda also included a religious dimension; communists were depicted not only as atheists but also as hostile to religion and religious people. Narratives about communist hatred toward believers abounded. A religious language started to be used for úlkücü deaths; those who died in the armed clashes were called "martyrs.",28 Anadol said that those who were killed on the NAP side were "şehit" (martyrs) ${ }^{29}$ and Túrkeş stated that 5500 of their friends were martyred. ${ }^{30}$ With this language, religious connotations of sacrifice in defense of religion, the country and honor were deployed against the left.

To further blur categories, the word "leftist" was used interchangeably with "communist militants," and all groups and individuals within the wide spectrum of the left 
were presented as threatening. Canefe argues that one of the main principles of the NAP was anti-communism, which sought an alliance against the left and absolutely refused to share political platform with them. ${ }^{31}$ Not only the NAP, but also other right-wing political parties contributed to the erasure of multiple distinctions to produce one deadly enemy, namely "the communist." Demirel, the leader of the main right-wing party (Justice Party), for instance, adopted anti-leftist and anti-communist rhetoric as a strategy to unite the right. He stated that he was ready to form a coalition against the left [which he indeed did, with the First and Second Nationalist Front Governments]. He also declared that he and his party were against all forms of leftism, including the Republican People's Party, which defined itself as the left-ofcenter party. Demirel said that it was normal that he did not share with the left any political platform. ${ }^{32}$ These words created a climate where everything defined by the right as leftist was vulnerable to physical attacks. ${ }^{33}$

The fact that the definition of the "enemy" broadened day by day also explains the expansion of target groups. The violent acts by NAP-related organizations increased after 1974. First, they targeted leaders and members of leftists youth organizations. Later on, especially during the Nationalist Front Government, targets included members of professional organizations such as the Confederation of Revolutionary Worker's Unions and Teachers' Association of Turkey (Devrimci Isçi Sendikalar and Türkiye Ö̆gretmenler Birliği). After that, intellectuals, university professors and journalists were also killed. ${ }^{34}$

This atmosphere left no space for neutrality. It was a typical case of "either you are with us, or you are against us." Indeed, Taşer declared that there was no place for neutrality between the struggles of the communists and nationalists in Turkey. ${ }^{35}$ If the communists won, Turkey would become a satellite of the Soviet Union, like Czechoslovakia, constantly open to intervention by the Soviets. He mentally divided Turkey into two blocks: the leftist forces and the rightist forces. On the left, he counted Turkish Radio and Television Institute (TRT, Türkiye Radyo Televizуопи), at that time the only TV channel in Turkey, academics, pro-Kurdish groups, opportunists, the Republican People's Party (Cumhuriyet Halk Partisi, CHP), the Turkish Workers' Party (Türkiye Iş̧̧i Partisi), Revolutionary Workers' Union (Disk), Revolutionary Teachers Association (Devrimci Ögretmenler Birliği), Revolutionary Turkish Women Association (Devrimci Türk Kadınları Birliği), Dev-Genç, Federation of Social Democracy Associations (SDDF, Sosyal Demokrasi Dernekleri Federasyonu), Assistants' Union (Asistanlar Sendikast) and so on. ${ }^{36}$ He argued that even the state should not try to remain neutral. According to Taşer, the state should be the major actor and it should take sides. He said that if the state in a communist country is communist, then a state in a nationalist country had to be nationalist and had to take side with the nationalists against the communists. He criticized the attitude of the state organs, calling it a mistake that they tried to assume the arbitrator's position and punish both nationalists and leftists. ${ }^{37}$

Unsurprisingly, Taşer's pupils at the Union of Hearths of Ideal (Ülkü Ocaklart Birliği) issued a declaration on March 17, 1971 that stated that no Turkish individual or institution can remain indifferent against those selling Turkey out to the communist 
bloc in the name of anti-imperialism. Otherwise, the Ülkü Ocakları Birliği declaration stated, international communism would end the life of the Turkish nation. Addressing the Turkish people, the declaration said, "If you want to live, do not forget and do not forgive! This is the existential struggle of the Turkish nation. It is only the úlkúcú nationalist Turkish youth that will save Turkey." 38 From these examples and from additional texts such as Anadol's Alparslan Türkeş, it is evident that Túrkeş and NAP-related organizations presented the NAP as the only alternative that could "save" what was valuable. They equated internal and external enemies with being enemies of the NAP.

After haven shown how threat narratives were supplied by elite discourse, the article will now turn to how the discourse was received in this story. In what follows, the article will demonstrate how participants in killings were impacted by the threat discourse.

\section{After the Storm: When Û́lkúcû́s Look Back}

Mehmet Ekici, former NAP vice-president, was imprisoned for three years after the 1980 military intervention. In his reflections on the time he spent in Ankara's Mamak prison, Ekici remembers his astonishment when he first realized how similar the leftist and rightist prisoners at Mamak were. The mothers who came to visits looked surprisingly similar. The reason he was surprised was that previously he and other úlkücüs always thought that the leftists were, as it were, "from Russia," while the leftists thought that the úlkücüs were "from the USA." He states that he was struck to see that both the leftists and the rightists became melancholic listening to the same folk songs. Previously, he said, he had thought that "they" would only sing the Communist International. ${ }^{39}$ Ekici's account illustrates how the civil war divided Turkey into two worlds, each of which saw the other one as the puppet of an external power and the mortal enemy.

Ốmer Tanlak had taken part in the radical right's political violence since 1975 . He was 19 years old on December 5, 1979, when he talked about the movement he left. In his "confessions," Tanlak said that he joined the Etlik Ülkü Ocă̆g (The Hearth of Ideal in Etlik) in 1975 thanks to a persuasive friend who told him that they would inhibit the Communists and that the only way to do that was through the Hearths of Ideal. ${ }^{40} \mathrm{He}$ also told a press conference in 1979 that he had believed the mission was sacred. Tanlak explained that he had been convinced that the leftist were external agents and were selling the country. He also added that the Etlik region was under the control of radical nationalists and that, for instance, anyone who was reading the Cumhuriyet ${ }^{41}$ newspaper in Etlik was beaten, ${ }^{42}$ another sign of how the left was seen as an enemy, indiscriminately and monolithically.

Another "confession" came years later on February 25, 2007 from Taylan Çoklar, an official member of the Adana Ülkü Ocaklarl (The Hearth of Ideal in the southern city of Adana) prior to the military intervention. In 1981, Çoklar was found guilty of establishing a group to commit crimes, including murder, attempted murder, shooting a house, and throwing explosives. He received three death penalties and 36 years of 
imprisonment. He remained in prison for 13 years until he benefited from the general pardon. In a newspaper interview, he said that he had been an ülkücü since his secondary school years when he was 13, and had joined Adana Ülkü Ocakları because he believed Turkey was under threat. ${ }^{43}$

Çoklar recalls how impressed he had been. The main thing they learned at Adana Ülkü Ocaklarl, he notes, was how bad communism was and that the communists wanted to divide the country. He had thought, "since they wanted to divide the homeland, all of them had to be killed." Çoklar took part in the fights with the leftists: first fist-to-fist, and then with guns. He said that the older members in the organization gave them the bombs and told them where to drop them. The younger ones, including Çoklar, did not question this order since they were convinced that they were doing this for the homeland. Finally, Çoklar adds that they wanted to be the heroes of their times and took over the mission to save the country. He said that at that time they had no alternative but to choose between the left and right, once more, showing the totalizing discourse of the time.

\section{Conclusion}

This article has shown that via threat narratives, first, groups identify a certain politically mobilized group as their enemy and inflict fear on others against this group. Threat narratives targeting leftist groups are widespread in the writings and speeches of political and intellectual cadres as well as contemporaneous media. It is also possible to trace their resonance on the perpetrators. In the examples, perpetrators were constantly reminded of the existential threat they were facing; they had to act if they wanted to survive and save their country, or so they were made to believe.

Secondly the article has illustrated how the immediate mobilized opposition groups (i.e. the militant leftist groups) are associated with a broader group of people who are not actually part of the violent conflict and with whom the armed group can only be associated on loose grounds. The propaganda was successful in conflating categories and labels in such a way that many groups who had nothing to do with the actual armed struggle collapsed into the category of the mortal enemy. Labels which were more likely to be seen as sources of imminent threat by the people were used interchangeably with other labels. The difference between faced threat and imaginary threat was blurred. For instance, since people were hearing horror stories about militants, these available narratives became the basis for expanding the fear, and hatred, to other groups that shared very little with these groups. In the Turkish case, the distinction between militant leftists who were engaged in armed conflict was blurred to include all other leftist people, such as intellectuals, trade unionists, judges, etc. The radical right used the word solcu (leftist) very often interchangeably with the words communist, anarchist, or militant. Fighting the left was presented as identical to fighting the enemies of democracy, enemies of the state, enemies of the religion and enemies of the nation. A common practice among the NAP members, including Túrkeş, was to label an association "proMoscow." 
Third, in addition to constantly reproducing and deliberately conflating and broadening the enemy, threat narratives were also used in order to blame and cast suspicion on neutral groups, moderates, and those advocating a path different from that followed by the úlkücú groups. These groups could also easily be put in the category of the enemy since they did not take sides in this "existential struggle." There was every reason to suspect that these were "accomplices" of the enemies but they were hiding this fact. There was no space left for neutrality in this atmosphere of fear and threat. This is a point where threat narratives and compulsion to violence come together. It is not sufficient to say that people were compelled, but it is also important to see the link between threat perceptions and this compulsion to take sides. The sides of the struggle were extended to such a degree (by collapsing many categories into the category of "the enemy") that the issue was presented as a total war, where the existence of "the people" was at stake. Anyone who said s/he wants to stay neutral served the interest of the other side and was also suspected of helping the enemy in other ways.

The analysis of a non-ethnic civil war shows us that we can broaden the role assigned to threat narratives in political violence to include different types of political conflict, and not ethnic conflict alone. It sets an agenda to further analyze the role of threat narratives in the mobilization of groups not just based on ethnic violence but political violence in general. This study also seeks to help us understand how collective violence is mobilized and encouraged and how it is increased with the snowballing of the category of the fatal enemy. The implication of this study is that threat narratives used by the political elite, by the media, or in educational material can serve as early warning systems for the potential mobilization of groups and escalation of violence in future cases. Perhaps we cannot easily detect how people are secretly compelled to take part in violence, but we can usually follow public propaganda in every country easily, which in turn can alert us to what is being potentially triggered, including the mass killings of civilians. If a society at large is encouraged to approach these narratives critically, participation in mass political violence might be reduced if not prevented altogether.

\section{Notes}

1. Kalyvas, The Logic of Violence in Civil War.

2. Tishkov, "Conflicts Start with Words," 80.

3. By threat narrative, I mean the framing of the conflict as a threat of loss rather than the chance of winning something, or as a feeling of victimhood and the prevention of victimization. See Elwert, Feuchtwang and Neubert, "The Dynamics of Collective Violence," 23 and Montville, "Epilogue: The Human Factor Revisited," 537, respectively.

4. Bar-Tal, "Why Does Fear Override Hope in Societies Engulfed by Intractable Conflict, as It Does in the Israeli Society?," 604-5.

5. Ricoeur, "Narrative Time," 169-90; MacIntyre, After Virtue: A Study in Moral Theory; Taylor, Sources of the Self: The Making of the Modern Identity; Bruner, "The Narrative Construction of Reality," 1-21.

6. Somers, "The Narrative Constitution of Identity," 605-49.

7. Smith, Stories of Peoplehood: The Politics and Morals of Political Memberships.

8. Rotherbart and Korostelina, "Identity, Morality and Threat: Studies in Violent Conflict," 1, 2, 5. 
9. I follow Kalyvas' definition of civil war, where it is "armed combat within the boundaries of a recognized sovereign entity between parties subject to a common authority at the outset of the hostilities." Kalyvas, The Logic of Violence in Civil War, 5.

10. Cited in Baştunc, Şu 68 Kuşağı.

11. The trials following the 1980 military coup illustrate this direct link. In a case opened against the NAP in 1981, the prosecutor prepared a 945 page-long indictment accusing both party members and úlkúcú organization leaders and executives for attempting to change the constitutional and democratic order of the republic in favor of a dictatorial rule and for killings by arming the Turkish society and participating in these killings. The party leader, Alparslan Tứrkeş, was sentenced to 11 years one month and 10 days imprisonment. Other verdicts included five capital punishments, nine life-long imprisonments, and 219 imprisonments ranging from six months to 36 years. Akpınar, 172.

12. Pekmezci and Búyúkyıldız, Ülkúcúler: Öteki Devletin Sehitleri, 77.

13. The radical right also formed various organizations around which it organized society. These include úlkúcü organizations for: teachers, technicians, police, civil servants, journalists, workers and farmers, among others. They also published various newspapers and journals addressing all sectors of the society, including women doctors, police, high school students.

14. Bozkurtlar means "grey wolves." It is taken from Turkish mythology in Central Asia. This name was used almost interchangeably with the úlkúcü due to the same links with NAP. The name úlkücübecame much more common and the term bozkurtlar was abolished as the party gained a more religious character because of its pre-Islamic origins. Akpınar, Kurtların Kardeşliği.

15. Landau, "The Nationalist Action Party in Turkey," 594.

16. In 1970, the government became concerned about these illegal establishments and wanted them to be investigated. According to the report prepared by the Ministry of Internal Affairs on 26 October 1970, commando camps were established by the Grey Wolves in order to fight the communists. This report gave in-depth information about the daily routine in these camps and included concerns about the similarities between the discourse and strategies in these camps and Nazi indoctrination.

17. Akpınar, Kurtların Kardeşliği, 57.

18. Cited in Akpınar, Kurtların Kardeşliği, 57.

19. Özdemir, Siyasal Tarih: 1960-1980, 280.

20. Robert Winslow, San Diego State University: A Comparative Criminology Tour of the World, http:// www-rohan.sdsu.edu/faculty/rwinslow/asia_pacific/turkey.html.

21. Taşer's writings in the Devlet newspaper were collected in Dứndar Taşer, Mesele; Akpınar, Kurtların Kardeşlĭği, 98.

22. Devlet, 30 March 1970, in Taşer, Mesele, 164.

23. Devlet, 20 April 1970, in Taşer, Mesele, 177.

24. Anadol, Alparslan Türkeş: Olaylar, Belgeler ve MHP, 277, 287.

25. Anadol, Alparslan Türkeş, 277.

26. Ibid., 288.

27. Ibid., 331.

28. Akpınar, Kurtların Kardeşliği, 105.

29. Anadol, Alparslan Türkeş, 286.

30. Ibid., 331.

31. Canefe, "Tribalism and Nationalism in Turkey," 161.

32. Ahmad, "Military Intervention and the Crisis in Turkey," 18.

33. Ibid.

34. Canefe, "Tribalism and Nationalism in Turkey," 163.

35. Taking this background into consideration, it comes as no surprise that judges were among the targets of the killings.

36. 20 July 1970, in Taşer, Mesele, 230-9.

37. 2 August 1971, in Taşer, Mesele, 411-14.

38. Cited in Akpınar, Kurtların Kardeşliği, 16393-4.

39. Cited in Akpınar, Kurtların Kardeşliği, 179. 
40. Tanlak, Itiraf: Eski Ülkúcü MHP'yi Anlatiyor, 13.

41. A leftist-secularist newspaper.

42. Tanlak, Itiraf: Eski Úlkúcü MHP'yi Anlatiyor, 33-4.

43. Şermin Terzi, "Ben söylüyorsam boşa söylemiyorum [I am saying this for a reason]," Hürriyet, 25 February 2007.

44. For instance, in one of his speeches, Tưrkeş says that the Revolutionary Teachers Association (TŐB-DER) is pro-Moscow. Anadol, Alparslan Türkeş, 125.

\section{Notes on Contributor}

Meral Ugur Cinar is Assistant Professor of Political Science at Bilkent University. She received her PhD in Political Science from the University of Pennsylvania in May 2012. She was Mellon Interdisciplinary Postdoctoral Fellow at the New School for Social Research in 2012-2013. She was selected the National Center for Institutional Diversity (NCID) Exemplary Diversity Scholar at the University of Michigan. She also co-authored an article that has won the 2013 Sabanci International Research Award. Her research interests include nationalism, citizenship, immigration, democracy, constitution making, collective memory, and social movements. Her articles are accepted for publication in PS: Political Science \& Politics, Political Studies, Middle Eastern Studies, and Turkish Studies as well as several edited book volumes.

\section{References}

Ahmad, Feroz. "Military Intervention and the Crisis in Turkey." MERIP Reports, no. 93 (January, 1981). Akpınar, Hakan. Kurtların Kardeşliği: CMKP'den MHP'ye (1965-2005) [The Brotherhood of Wolves: From CMKP to MHP]. Istanbul: Bir Harf, 2005.

Anadol, Cemal. Alparslan Türkeş: Olaylar, Belgeler ve MHP, Hatıralar [Alparslan Tứrkeş: Events, Documents, and the MHP]. Ankara: Burak, 1995.

Bar-Tal, Daniel. "Why Does Fear Override Hope in Societies Engulfed by Intractable Conflict, as It Does in the Israeli Society?" Political Psychology 22, no. 3 (September, 2001): 601-627.

Baştunc, Yúksel. Şu 68 Kuşağı [The 1968 Generation]. Istanbul: Yılmaz Yayınları, 1992.

Bruner, Jerome. "The Narrative Construction of Reality." Critical Inquiry 18, no. 1 (Autumn, 1991): 1-21.

Canefe, Nergis. "Tribalism and Nationalism in Turkey: Reinventing Politics." In Ethnic Conflict, Tribal Politics: A Global Perspective, edited by Kenneth Christie, 153-173. London: Curzon Press, 1998.

Elwert, Georg, Stephen Feuchtwang, and Dieter Neubert. "The Dynamics of Collective Violence: An Introduction." In Dynamics of Violence: Processes of Escalation and De-escalation in Violent Group Conflicts, edited by Georg Elwert, Stephen Feuchtwang and Dieter Neubert, 7-31. Berlin: Dunker \& Humboldt, 1999.

Kalyvas, Stathis. The Logic of Violence in Civil War. Cambridge: Cambridge University Press, 2006.

Landau, Jacob M. "The Nationalist Action Party in Turkey." Journal of Contemporary History 17, no. 4 (October 1982): 587-606.

MacIntyre, Alasdair. After Virtue: A Study in Moral Theory. 3rd ed. Notre Dame: University of Notre Dame Press, 2007 (1981).

Montville, Joseph V. "Epilogue: The Human Factor Revisited." In Conflict and Peacemaking in Multiethnic Societies, edited by Joseph V. Montville, 535-541. Toronto: Lexington Books, 1990.

Ôzdemir, Hikmet. Siyasal Tarih: 1960-1980 [Political History: 1960-1980], in Sina Akşin (ed.) Tưrkiye Tarihi 4: Çağdaş Türkiye 1908-1980. Istanbul: Cem, 1997.

Pekmezci, Necdet and Nurşen Búyúkyıldız. Ülkücúler: Öteki Devletin Sehitleri [Ứlkúcús: The Martyrs of the Other State]. Istanbul: Kaynak, 1999.

Ricoeur, Paul. "Narrative Time." Critical Inquiry 7, no. 1, On Narrative (Autumn, 1980), 169-190.

Rotherbart, Daniel, and Karina V. Korostelina. "Identity, Morality and Threat: Studies in Violent Conflict." In Identity, Morality and Threat, edited by D. Rotherbart and K. V. Korostelina, 1-15. Toronto: Lexington Books, 2006. 
Smith, Rogers. Stories of Peoplehood: The Politics and Morals of Political Memberships. Cambridge: Cambridge University Press, 2003.

Somers, Margaret R. "The Narrative Constitution of Identity: A Relational and Network Approach." Theory and Society 23, no. 5 (October, 1994): 605-649.

Tanlak, Ômer. Itiraf: Eski Ülkúcü MHP'yi Anlatiyor [Confessions: An ex-Ǘlkúcú Explains MHP]. Istanbul: Kaynak, 1997.

Taşer, Dűndar. Mesele [The Matter]. Ankara: Tôre-Devlet, 1973.

Taylor, Charles. Sources of the Self: The Making of the Modern Identity. Cambridge: Harvard University Press, 1989.

Terzi, Şermin. "Ben söylüyorsam boşa söylemiyorum [I am saying this for a reason]," Hürriyet, 25 February 2007.

Tishkov, Valery A. "Conflicts Start with Words: Fighting Categories in the Chechen Conflict." In Facing Ethnic Conflict: Toward a New Realism, edited by Andreas Wimmer et al. Lanham: Rowman and Littlefield, 2004.

Winslow, Robert. San Diego State University: A Comparative Criminology Tour of the World. Accessed February 19, 2014. http://www-rohan.sdsu.edu/faculty/rwinslow/asia_pacific/turkey.html 